\title{
The Effect of Environmental Management Accounting, Environmental Strategy on Environmental Performance and Financial Performance Moderated By Managerial Commitment
}

\author{
${ }^{1}$ Eko Cahyo Mayndarto \\ ${ }^{1}$ Faculty Of Economincs And Business. Trisakti Univercity \\ ${ }^{2}$ Yvonne Agustine \\ ${ }^{2}$ Faculty Of Economincs And Business. Trisakti Univercity \\ ${ }^{*}$ Corresponding author: \\ Email: ekocmayndarto@gmail.com
}

\begin{abstract}
.
Environmental management (EMA) has been considered as a successful idea to reduce ecological burdens in the form of energy dependence and carbon footprint. In addition to the company's highest emphasis on EMA, the organization's environmental strategy (ENS) is articulated and implemented with ecological motivation. The role of the ENS strengthens the internal awareness of the organization to improve environmental conditions and thereby helps reduce negative environmental stresses. In addition, with increasing environmental regulations in place, the need for sound environmental policies and strategies of the company is essential to protect future growth and market image. Results There is a significant influence of environmental management accounting to encourage environmental performance, there is a significant effect of environmental management accounting to encourage economic performance, there is a significant influence of environmental strategy to encourage environmental performance, there is a significant influence of environmental strategy to encourage economic performance, commitment to moderate management The significant influence of Environmental Management Accounting to encourage Environmental Performance, Management Commitment Cannot Moderate the Effect of Environmental Management Accounting which encourages Economic Performance, Management Commitment to Moderate the significant influence of Environmental Strategy to encourage Environmental Performance and Management Commitment to Moderate the Impact of Environmental Strategy which is significant to encourage Economic Performance.
\end{abstract}

Keywords: Environmental Management, Environmental Strategy, Environmental Performance, Financial Performance, Managerial Commitment

\section{INTRODUCTION}

At present, carbon and other emissions that destroy ozone are one of the drivers behind this research (Mancini et al., 2016); (Haruna \& Mahmood, 2018). Environmental conditions, currently, are experiencing a major decline. This shows that humans, today, exert a higher pressure on the ecological atmosphere. Carbon and other ozone-depleting emanations are one of the fundamental drivers of this research. Additionally, industry has been a major producer of ozone depleting substances, past

http://ijstm.inarah.co.id 
and present. To reduce negative ecological effects including emanated carbon, environmental management has been shown to be beneficial.

In the field of accounting, environmental management accounting (EMA) has been considered a successful idea to reduce the ecological burden in the form of energy dependence and carbon footprint. In the same context, several EMA features in the form of material flow costs, sustainability balanced scorecard, and ecological control (eco-control) were found to be useful in identifying firm effects on ecological conditions (Aliakbari Nouri et al., 2019); (Jasch, 2008); (Henri \& Journeault, 2018); (Lu et al., 2018). The focus of previous studies examining the role of environmental accounting is limited to identifying costs associated with firm processes that can disrupt ecological conditions. In this regard, most of the research examines environmental impact and cost measures (Epstein, 1996); (Parker, 1997); (Jasch, 2003); (Gale, 2006); (Hye \& Jafri, 2011). While the focal point of natural and social accounting on past examinations reveals in a transparent manner the existence of ecological exposure, EMA has been progressively exploited and explored as a management tool to address the ecological burden of companies and old practice practices (Qian et al., 2018). Therefore, it has been recognized that EMA can take an important role to encourage impartiality towards operations as a change towards reducing the company's ecological effects and thereby improving the company's environmental management practices (Schaltegger, 2018); (Hossain et al., 2018).

In addition to the firm's highest emphasis on EMA, the organization's environmental strategy (ENS) is articulated and implemented with ecological motivation (Phan et al., 2018). The role of the ENS strengthens the internal awareness of the organization to improve environmental conditions and thereby helps reduce negative environmental stresses. In addition, with increasing environmental regulations in place, the need for sound environmental policies and strategies of the company is essential to protect future growth and market image. In this case, the company's strategy is related to environmental (ecological) procedures to reduce energy dependence along with controlling all forms of pollution, use of recycled materials, utilization of green materials.

The organization's increased environmental awareness cannot succeed in achieving its sustainability goals without management support. In this case, managerial commitment (MAC) to ecological improvement is important for achieving productive organizational growth. In many ecological processes, organizations have to face the difficult trade-off between monetary benefits and rising costs. In such circumstances, MAC is needed to reinforce the organization's ecologically driven goals of financial gain. However, many studies believe that a company's efficient environmental policies not only limit the ability to improve environmental performance (ENP) but also improve organizational economic performance (ECP).

This study aims to investigate the relationship between environmental management accounting in realizing company performance. Therefore, the current research chooses to determine the effect of environmental management accounting 
(EMA), environmental strategy (ENS) in driving firm performance. Given the current concern that environmental problems in organizations will actually increase financial costs, and this study is also motivated to analyze the impact of variables on environmental performance (ENP) and economic performance (ECP) moderated by managerial commitment (MAC) in the Home Industry in Jabodetabek.

\section{METHOD}

The object of research is something of concern in research. The object of this research is the target of research to get answers or solutions to problems that occur. The research object is an object that will be researched, analyzed and studied. In this study, the research object determined by the author in accordance with the problems under study is Environmental Management Accounting, Environmental Strategy, Economic Performance, Environmental Performance and Manager's Commitment. The place of research that will be the object of research is Home Industry Actors in Jabodetabek.

In quantitative research, data analysis is an activity after collecting data from all respondents. In conducting data analysis, accurate and untrustworthy data is needed which will later be used in research conducted by the author.

\section{RESULT AND DISCUSSION}

The following is the Loading Factor generated by the structural model, where if the calculated $\mathrm{T}$ value is greater than the $\mathrm{T}$ table value, it is significant:

Table 1. Hypothesis

\begin{tabular}{|c|c|c|c|c|c|}
\hline Hypothesis & Effect & $\begin{array}{c}\text { Path } \\
\text { tkritic }\end{array}$ & $\mathbf{t}_{\text {count }}$ & $\mathbf{t}_{\text {critical }}$ & Information \\
\hline H1 & EMA > ENP & 0.380 & 7.37 & \pm 1.96 & Accepted \\
\hline H2 & EMA > ECP & 0.460 & 6.14 & \pm 1.96 & Accepted \\
\hline H3 & ENS > ENP & 0.450 & 7.25 & \pm 1.96 & Accepted \\
\hline H4 & ENS > ECP & 0.310 & 3.85 & \pm 1.96 & Accepted \\
\hline H5 & EMA > MAC > ENP & -0.190 & -4.89 & \pm 1.96 & Accepted \\
\hline H6 & EMA > MAC > CP & -0.059 & -1.15 & \pm 1.96 & Rejected \\
\hline H7 & ENS > MAC > ENP & 0.084 & 1.99 & \pm 1.96 & Accepted \\
\hline H8 & ENS > MAC > CP & 0.180 & 3.08 & \pm 1.96 & Accepted \\
\hline
\end{tabular}

The table above is a hypothetical test of the statistical calculation results, with the following conclusions:

1. Significant influence of Environmental Management Accounting on environmental performance. The path coefficient between Environmental Management Accounting and Environmental Performance is 0.380 which is positive. This means that the higher the Environmental Management Accounting, the environmental performance will increase. 
2. Significant influence of Environmental Management Accounting on economic performance. The path coefficient between Environmental Management Accounting and Environmental Performance is 0.460 which is positive. This means that the higher the Environmental Management Accounting, the higher the economic performance will be.

3. Significant influence of Environmental Strategy in encouraging environmental performance. The path coefficient between Environmental Strategy and Environmental Performance is 0.450 which is positive. This means that the higher the environmental strategy, the environmental performance will increase.

4. The significant influence of environmental strategy in driving economic performance. The path coefficient between Environmental Strategy and Environmental Performance is 0.310 which is positive. This means that the higher the environmental strategy, the higher the economic performance will be.

5. Management Commitment to Moderate the significant influence of Environmental Management Accounting to encourage environmental performance. The path coefficient between Environmental Management Accounting for Environmental Performance is 0.190 which is negative. This means that the higher the Environmental Management Accounting, the environmental performance will decrease if moderated by management commitment.

6. Management Commitment Cannot Moderate the Effect of Environmental Management Accounting to Improve Economic Performance. The path coefficient between Environmental Management Accounting and Environmental Performance is 0.059 which is negative. This means that the higher the Environmental Management Accounting, the lower the economic performance will be if moderated by management commitment.

7. Management Commitment to Pay Attention to the Significant Impact of Environmental Strategies to Improve Environmental Performance. The path coefficient between Environmental Management Accounting and Environmental Performance is 0.084 which is positive. This means that the higher the environmental strategy, the environmental performance will increase if moderated by management commitment.

8. Management's Commitment to Moderate the Significant Effects of Environmental Strategies to Improve Economic Performance. The path coefficient between Environmental Strategy and Environmental Performance is 0.180 which is positive. This means that the higher the environmental strategy, the higher the economic performance if moderated by management commitment. Management's Commitment to Moderate the Significant Effects of Environmental Strategies to Improve Economic Performance 


\section{CONCLUSION}

There is a significant effect of environmental management accounting to encourage environmental performance, there is a significant influence of environmental management accounting to encourage economic performance, there is a significant influence of environmental strategy to encourage environmental performance, there is a significant influence of environmental strategy to encourage economic performance, management commitment moderates the influence Environmental Management Accounting which is significant to encourage Environmental Performance, Management Commitment Cannot Moderate the Influence of Environmental Management Accounting which encourages Economic Performance, Management Commitment to Moderate the Impact of Environmental Strategy which is significant to encourage Environmental Performance and Management Commitment to Moderate the Impact of Environmental Strategy which is significant to drive Economic Performance.

\section{REFERENCES}

[1] Abdallah, A. B., Phan, A. C., \& Matsui, Y. (2016). Investigating the effects of managerial and technological innovations on operational performance and customer satisfaction of manufacturing companies. International Journal of Business Innovation and Research. $\mathrm{https} / / / \mathrm{doi} .0 \mathrm{~g} /$ 10.1504/IJBIR.2016.074824

[2] Aliakbari Nouri, F., Shafiei Nikabadi, M., \& Olfat, L. (2019). Developing the framework of sustainable service supply chain balanced scorecard (SSSC BSC). International Journal of Productivity and Performance Management. https://doi.org/10.1108/IJPPM-04-2018-0149

[3] Aragón-Correa, J. A., Hurtado-Torres, N., Sharma, S., \& García-Morales, V. J. (2008). Environmental strategy and performance in small firms: A resource-based perspective.
Journal
of
Environmental
Management. https://doi.org/10.1016/j.jenvman.2006.11.022

[4] Bansal, P., \& Roth, K. (2000). Why companies go green: A model of ecological responsiveness. Academy of Management Journal. https://doi.org/10.2307/1556363

[5] Claver-Cortés, E., Molina-Azorín, J. F., Pereira-Moliner, J., \& López-Gamero, M. D. (2007). Environmental strategies and their impact on hotel performance. Journal of Sustainable Tourism. https://doi.org/10.2167/jost640.0

[6] Epstein, M. J. (1996). Improving environmental management with full environmental cost accounting. Environmental Quality Management. https://doi.org/10.1002/tqem.3310060104

[7] Gale, R. (2006). Environmental costs at a Canadian paper mill: a case study of Environmental Management Accounting (EMA). Journal of Cleaner Production. https://doi.org/10.1016/j.jclepro.2005.08.010

[8] Ghozali, I., Ulum, I., \& Chariri, A. (2014). Intellectual Capital Dan Kinerja Keuangan Perusahaan; Suatu Analisis Dengan Pendekatan Partial Least Squares. Simposium Nasional Akuntansi XI.

[9] Gong, Y., Law, K. S., Chang, S., \& Xin, K. R. (2009). Human Resources Management http://ijstm.inarah.co.id 
and Firm Performance: The Differential Role of Managerial Affective and Continuance Commitment. Journal of Applied Psychology. https://doi.org/10.1037/a0013116

[10] Hartono, J. (2013). Teori Fortofolio dan Analisis Investasi. Edisi Kedelapan. Metodologi Penelitian Bisnis.

[11] Haruna, M. A., \& Mahmood, S. (2018). Impact of Energy Consumption and Environmental Pollution in Malaysia. Energy Economics Letters. https://doi.org/10.18488/journal.82.2018.51.31.43

[12] Haseeb, M., Hussain, H. I., Ślusarczyk, B., \& Jermsittiparsert, K. (2019). Industry 4.0: A solution towards technology challenges of sustainable business performance. Social Sciences. https://doi.org/10.3390/socsci8050154

[13] Haseeb, M., Zandi, G., Hartani, N. H., Pahi, M. H., \& Nadeem, S. (2019). Environmental analysis of the effect of population growth rate on supply chain performance and economic growth of Indonesia. Ekoloji.

[14] Henri, J. F., \& Journeault, M. (2018). Antecedents and consequences of eco-control deployment: Evidence from canadian manufacturing firms. Accounting Perspectives. https://doi.org/10.1111/1911-3838.12168

[15] Hossain, M. A., Jahan, N., Islam, S., \& Chowdhury, S. P. (2018). The Antecedents of Word-of-Mouth Attitude in Mobile Advertising: An Experimental Study. International Journal of Asian Social Science. https://doi.org/10.18488/journal.1.2018.86.296.305

[16] Hye, Q. M. A., \& Jafri, Z. (2011). Trade, human capital and agricultural sector growth of Pakistan economy. African Journal of Agricultural Research. https://doi.org/10.5897/AJAR11.729

[17] Jasch, C. (2003). The use of Environmental Management Accounting (EMA) for identifying environmental costs. Journal of Cleaner Production. https://doi.org/10.1016/S0959-6526(02)00107-5

[18] Jasch, C. (2008). Environmental and Material Flow Cost Accounting: principles and procedures. In Journal of Chemical Information and Modeling.

[19] Jermsittiparsert, Kitisak, Siam, M. R. A., Issa, M. R., Ahmed, U., \& Pahi, M. H. (2019). Do consumers expect companies to be socially responsible? The impact of corporate social responsibility on buying behavior. Uncertain Supply Chain Management. https://doi.org/10.5267/j.uscm.2019.1.005

[20] Jermsittiparsert, Kittisak. (2016). Culture of "elephant front legs-hind legs": A debate on the actuality of sexual politics in Thai society. Social Sciences (Pakistan). https://doi.org/10.3923/sscience.2016.20.28

[21] Johnstone, L. (2018). Theorising and Modelling Social Control in Environmental Management Accounting Research. In Social and Environmental Accountability Journal. https://doi.org/10.1080/0969160X.2017.1422778

[22] KEHO, Y. (2017). The Exports and Economic Growth Nexus in Cote D ivoire: Evidence from a Multivariate Time Series Analysis. Asian Journal of Economic Modelling. https://doi.org/10.18488/journal.8/2017.5.2/8.2.135.146

[23] Latan, H., Chiappetta Jabbour, C. J., Lopes de Sousa Jabbour, A. B., Wamba, S. F., \& Shahbaz, M. (2018). Effects of environmental strategy, environmental uncertainty and top management's commitment on corporate environmental performance: The role of environmental management accounting. Journal of Cleaner Production. 
https://doi.org/10.1016/j.jclepro.2018.01.106

[24] Lu, M. T., Hsu, C. C., Liou, J. J. H., \& Lo, H. W. (2018). A hybrid MCDM and sustainability-balanced scorecard model to establish sustainable performance evaluation for international airports. Journal of Air Transport Management. https://doi.org/10.1016/j.jairtraman.2018.05.008

[25] Mancini, M. S., Galli, A., Niccolucci, V., Lin, D., Bastianoni, S., Wackernagel, M., \& Marchettini, N. (2016). Ecological Footprint: Refining the carbon Footprint calculation. Ecological Indicators. https://doi.org/10.1016/j.ecolind.2015.09.040

[26] Nakos, G., Brouthers, K. D., \& Eliotbrouthers, L. (1998). The impact of firm and managerial characteristics on small and medium-sized greek firms' export performance. Journal of Global Marketing. https://doi.org/10.1300/J042v11n04_03

[27] Parker, L. D. (1997). Accounting for Environmental Strategy: Cost Management, Control and Performance Evaluation. Asia-Pacific Journal of Accounting. https://doi.org/10.1080/10293574.1997.10510518

[28] Phan, T. N., Baird, K., \& Su, S. (2018). Environmental activity management: its use and impact on environmental performance. Accounting, Auditing and Accountability Journal. https://doi.org/10.1108/AAAJ-08-2016-2686

[29] Prajogo, D. I. (2016). The strategic fit between innovation strategies and business environment in delivering business performance. International Journal of Production Economics. https://doi.org/10.1016/j.ijpe.2015.07.037

[30] Qian, W., Hörisch, J., \& Schaltegger, S. (2018). Environmental management accounting and its effects on carbon management and disclosure quality. Journal of Cleaner Production. https://doi.org/10.1016/j.jclepro.2017.11.092

[31] Ridha, M. A., \& Basuki, H. (2012). The Impact of External Pressure, Environmental Uncertainty, and Commitment of Management on Implementation of Financial Reporting Transparency. The Indonesian Journal of Accounting Research.

[32] Santoso, S. (2012). Panduan Lengkap SPSS Versi 20. In PT Elex Media Komputindo.

[33] Schaltegger, S. (2018). Linking Environmental Management Accounting: A Reflection on (Missing) Links to Sustainability and Planetary Boundaries. Social and Environmental Accountability

Journal. https://doi.org/10.1080/0969160X.2017.1395351

[34] Sugiyono. (2016). Memahami Penelitian Kualitatif. Bandung: Alfabeta.

[35] Venkatraman, N., \& Prescott, J. E. (1990). Environment-strategy coalignment: An empirical test of its performance implications. Strategic Management Journal. https://doi.org/10.1002/smj.4250110102

[36] Vento, M. O., Alcaraz, J. L. G., Macías, A. A. M., \& Loya, V. M. (2016). The impact of managerial commitment and kaizen benefits on companies. Journal of Manufacturing Technology Management. https://doi.org/10.1108/JMTM-02-20160021

[37] Zhu, Q., Liu, J., \& Lai, K. H. (2016). Corporate social responsibility practices and performance improvement among Chinese national state-owned enterprises. International Journal of Production Economics. https://doi.org/10.1016/j.ijpe.2015.08.005

[38] Zhu, Q., Sarkis, J., \& Lai, K. hung. (2013). Institutional-based antecedents and 
performance outcomes of internal and external green supply chain management practices. Journal of Purchasing and Supply Management. https://doi.org/10.1016/j.pursup.2012.12.001 